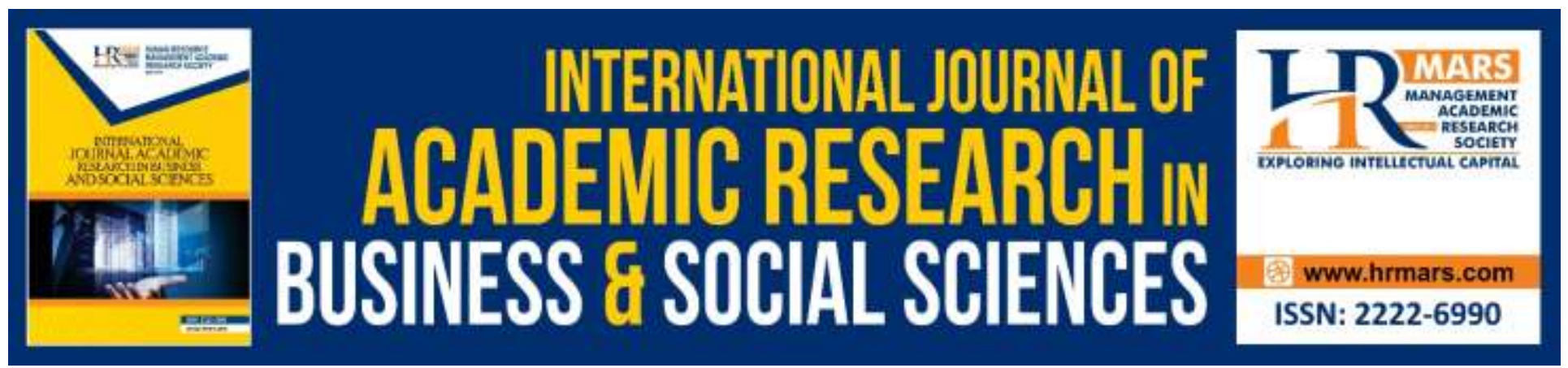

\title{
Mediating Role of Work Engagement and Emotional Exhaustion in the Effect of Work-Family Conflict on Female Workers' Turnover Intention
}

Putu Vivi Sinthya Purwayoga, Ida Bagus Agung Dharmanegara, Putu Ngurah Suyatna Yasa

To Link this Article: http://dx.doi.org/10.6007/IJARBSS/v9-i7/6101

DOI: $10.6007 /$ IJARBSS/v9-i7/6101

Received: 07 May 2019, Revised: 16 June 2019, Accepted: 03 July 2019

Published Online: 27 July 2019

In-Text Citation: (Purwayoga, Dharmanegara, \& Yasa, 2019)

To Cite this Article: Purwayoga, P. V. S., Dharmanegara, I. B. A., \& Yasa, P. N. S. (2019). Mediating Role of Work Engagement and Emotional Exhaustion in the Effect of Work-Family Conflict on Female Workers' Turnover Intention. International Journal of Academic Research in Business and Social Sciences, 9(7), 176-190.

Copyright: (C) 2019 The Author(s)

Published by Human Resource Management Academic Research Society (www.hrmars.com)

This article is published under the Creative Commons Attribution (CC BY 4.0) license. Anyone may reproduce, distribute, translate and create derivative works of this article (for both commercial and non-commercial purposes), subject to full attribution to the original publication and authors. The full terms of this license may be seen

at: http://creativecommons.org/licences/by/4.0/legalcode

Vol. 9, No. 7, 2019, Pg. 176 - 190

http://hrmars.com/index.php/pages/detail/IJARBSS

JOURNAL HOMEPAGE

Full Terms \& Conditions of access and use can be found at http://hrmars.com/index.php/pages/detail/publication-ethics 


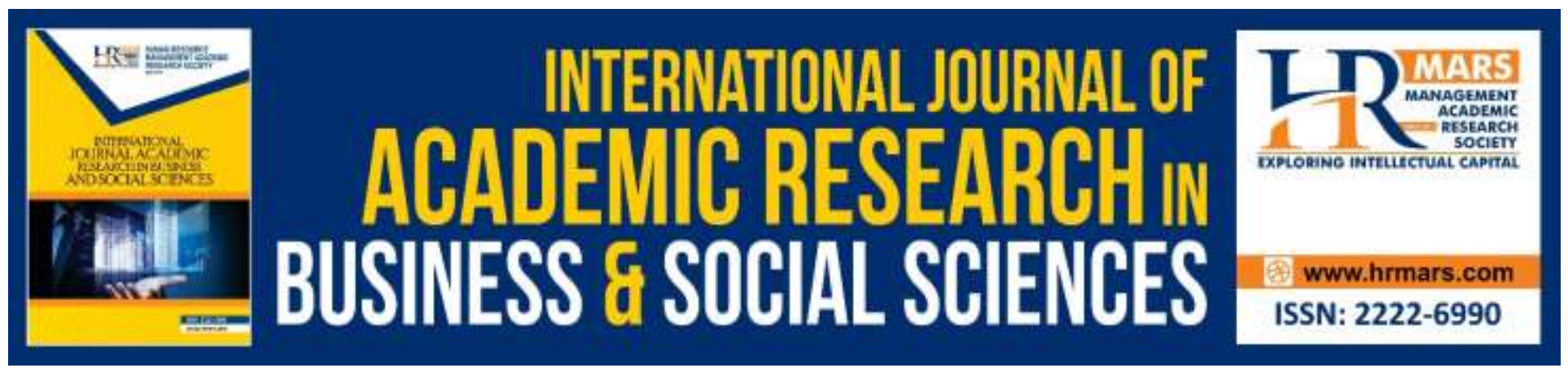

\title{
Mediating Role of Work Engagement and Emotional Exhaustion in the Effect of Work-Family Conflict on Female Workers' Turnover Intention
}

\author{
Putu Vivi Sinthya Purwayoga, Ida Bagus Agung Dharmanegara, \\ Putu Ngurah Suyatna Yasa \\ Magister of Management, Faculty of Economic, Warmadewa University, Denpasar, Bali, Indonesia
}

\begin{abstract}
The current research investigated women employees' use of work-family conflict and relationship to turnover intention, in which work engagement and emotional exhaustion used as intervening variables for mediating effect in the conceptual model that tested in this study. Data gathered from female officers from rural banks in sub district Badung, Denpasar Bali were used to test the relationships among variables. The findings show that the only one category of employees included in the research, that is women officer who works in rural bank in Mengwi Sub district Bali would consider to exit the organization when the work-family conflict they perceived. Not all of hypotheses were confirmed. Contrary to expectations, work-family conflict founded to be negatively not significant in affecting work engagement among female officers, thus work engagement could not significantly affect turnover intention. The study addresses concerns about the importance of the emotional exhaustion construct in the literature, particularly in its role in the relationship between work -family conflict and turnover intention.
\end{abstract}

Keywords: Work-family Conflict, Work Engagement, Emotional Exhaustion, Turnover Intention, Women Officer.

\section{Introduction}

Changes in workplaces and employee demographics have encouraged studies of the relationship between work and family to be more important than ever before Greenhaus \& Powell (2006). The division of labor with gender lines is not really a big deal, but difficulties arise when the labor of division considers greater strength, rights, roles, and authority concerning the role that more played by men than women Reed, Kratchman, \& Strawser, (1994). Historically, a role system based on sex in which showing that men have more power and control over resources than women has been preserved and perpetuated across cultures and for centuries. This condition is reinforced by the general opinion that women naturally not required have to work. But nowadays, it turns out now 
that women have equal degree with men in terms of employment. This would bring into a dual role conflict for women as a housewife and as a worker.

Lilly, Duffy, \& Virick, (2006) assess social structure in society, found that cultural pressure tends to be more directed at women who are required to take primary responsibility in managing family affairs and household. Therefore women tend to be more experiencing higher work-family conflict than men does. Women like this have a dual role as mothers and also as employees. Handini, Haryoko, \& Yulianto, (2014) added that one impact of these dual role is about not enough time for a woman who wants to spend time with her family and children. In a long term, this condition would lead into greater intention for women officers to exit from their organization who have could not cope with this situation.

As an important effort for companies to prevent turnover is a program in managing their human resources, one of which is an employee engagement program. It is also known that work engagement is a form of way of increasing productivity from a group of talented employees in the organization Santosa \& Cintya, (2012). In addition, employees who have a high level of energy and enthusiasm for their work will encourage feelings of bond and even drowning in their work so that time feels fleeting for them Schaufeli \& Bakker, (2004). This form of work engagement is positive (Saks, 2006), also Schaufeli \& Bakker, (2004) describe that besides work attachments, job burnout tend to be negative form of attitudinal mechanism. Job burnout is one form of pressure in work (Christina Maslach, Schaufeli, \& Leiter, 2001), and emotional exhaustion is an emphasis reaction where the reaction emphasizes the emotions, thoughts, physical and behavioral components of a person. This form of exhaustion lies in the physical characterized by negativity, rigidity, ignorance, guilt and difficulty in making decisions (Greenberg \& Baron, 2008). Wright \& Cropanzano, (1998) underline the form of the core meaning of job burnout is emotional exhaustion, as has been supported empirically by previous researchers (Cordes, Dougherty, \& Cordes, 1993; Lee \& Ashforth, 1993).

Several previous studies have revealed important and positive linkages between burnout and turnover intention (Hang-yue, Foley, \& Loi, 2005; W. B. Schaufeli \& Bakker, 2004; Wright \& Cropanzano, 1998; Yavas, Babakus, \& Karatepe, 2008). Specifically, Knudsen, Ducharme, \& Roman, (2006) explained that there is an important influence of emotional exhaustion on turnover intention. Although among the previous researchers there was one study that revealed that emotional exhaustion is not important for turnover intention (Geurts, Schaufeli, \& Jonge, 1998).

There are inconsistencies in empirical results in the pattern of the relationship between workfamily conflict in which related with turnover intention. There are results of previous studies showing that work-family conflict actually affects turnover intention negatively (Hang-yue et al., 2005; Panatik, Badri, Rajab, Rahman, \& Shah, 2011), which means that the higher work-family conflicts that occur will actually decrease the tendency of employees to leave the organization. In addition, other successful empirical evidence has been shown to conclude that work-family conflict does not have an important role in impacting turnover intention (Balmforth \& Gardner, 2006; Lathifah, 2008; Zhang, Griffeth, \& Fried, 2012). The negative relationship between turnover intention and job insecurity shows that women in public companies are actively involved in their perceptions of perceived job insecurity (Ribeiro, Bosch, \& Becker, 2016). This obviously greatly influences the decision to stay or leave the organization. The brief description of previous empirical results that have been successful identified and implies several research gaps, including: 
INTERNATIONAL JOURNAL OF ACADEMIC RESEARCH IN BUSINESS AND SOCIAL SCIENCES Vol. 9, No. 7, July, 2019, E-ISSN: 2222-6990 @ 2019 HRMARS

1. There are inconsistencies resulting from the effect of work-family conflict (WFC) on employee Turnover Intention. The nature of the influence is positive (Boles, Johnston, \& Hair, 1997; Haar, 2004; Noor \& Maad, 2008; Yavas et al., 2008), found to be negative (Hang-yue et al., 2005; Panatik et al., 2011); and at the same time not important (Balmforth \& Gardner, 2006; Lathifah, 2008; Zhang et al., 2012).

2. The inconsistency of results arises from the effect of job engagement on turnover intention (insignificant results, Mxenge, Dywili, \& Bazana, 2014) and job burnout on turnover intention (Geurts et al., 1998).

These two points indicate that the antecedents of turnover intention tested can provide mixed results. This is also considered as a gap and empirical basis of this research. All three: work-family conflicts, work engagement and emotional exhaustion are examined as antecedents of turnover intention and are built within the framework of an integrative model among the three. Based on the phenomena described above indirectly will have an impact on increasing turnover intention on workers, especially female officers at BPR in Mengwi, Bali. It is considered important to be able to know and overcome the factors that influence turnover intention, especially for female officers, as manager able to control the turnover that occurs in a company. Therefore, researchers are interested in choosing the theme of turnover intention on female officers who are affected by work-family conflict, emotional exhaustion and work engagement to work on female officers who work in BPR in Mengwi, Bali.

\section{Literature Review and Hypotheses Development}

The desire of employees to exit organization (turnover intention) refers to the results of individual evaluations regarding the employment relationships with organizations that have not been realized in leaving the organization. This willingness to move could be considered as the result of an individual's perceived conflict. Netemeyer, Boles, \& McMurrian, (1996) found that work-family conflict is directly related to turnover intention. As work-family conflict related with turnover intention, the relationship is depends on dimensions of work-family conflict itself (Noor \& Maad, 2008; Yavas et al., 2008). In addition, findings of previous studies indicate that emotional exhaustion lead to greater turnover intention (W. B. Schaufeli \& Bakker, 2004; Wright \& Cropanzano, 1998). Stress in the job that occurs in a long time would lasts in high intensity results in individuals experience while facing physical and emotional exhaustion. This condition is considered as "burnout" (Christina Maslach \& Jackson, 1981), which is seen as one form of stress that appears in individual behavioral attitudes. Exhaustion will lead to anxiety, depression, and decrease in self-esteem and increased health problems. Emotional exhaustion also happen in the work environment and has negative spillover that could affect people's household life (Christina Maslach et al., 2001). Emotional exhaustion is an emotional condition in which a person feels tired and saturated mentally or physically as a result of the increasing of work demand. Exhaustion could lead to anxiety, depression, an decreasing in self-esteem and increased health problems (Maslach \& Leiter, 1997; Maslach et al., 2001). But even though exhaustion is often perceived as a form of negative attitude in work (Christina Maslach \& Leiter, 1997), there is actually a form of positive work attitude and the opposite of exhaustion, which considered as work or job engagement (Schaufeli \& Bakker, 2010). Exhaustion and attachment could be interrelated with each other considering the nature of the relationship among 
them (Schaufeli et al., 2006; Schaufeli et al., 2002). But exhaustion in job (both job burnout and emotional exhaustion) has been identified as better to predict work attachments (Bakker, Demerouti, \& Sanz-Vergel, 2014; Schaufeli \& Bakker, 2010) than forms of conflict such as work-family conflict (Kesumaningsari \& Simarmata, 2014). This is argued by previous author considering that there are still quite a few findings that reveal the link between work-family conflict and job engagement (Baka \& Derbis, 2012). Besides emotional exhaustion, individual's attachment to work is also related with turnover intention (Agoi, 2015; Thirapatsakun, Kuntonbutr, \& Mechinda, 2014). The framework of the research model is built based on the description in theoretical and empirical studies and describes the overall hypothesis of this research shown in the figure as follows:

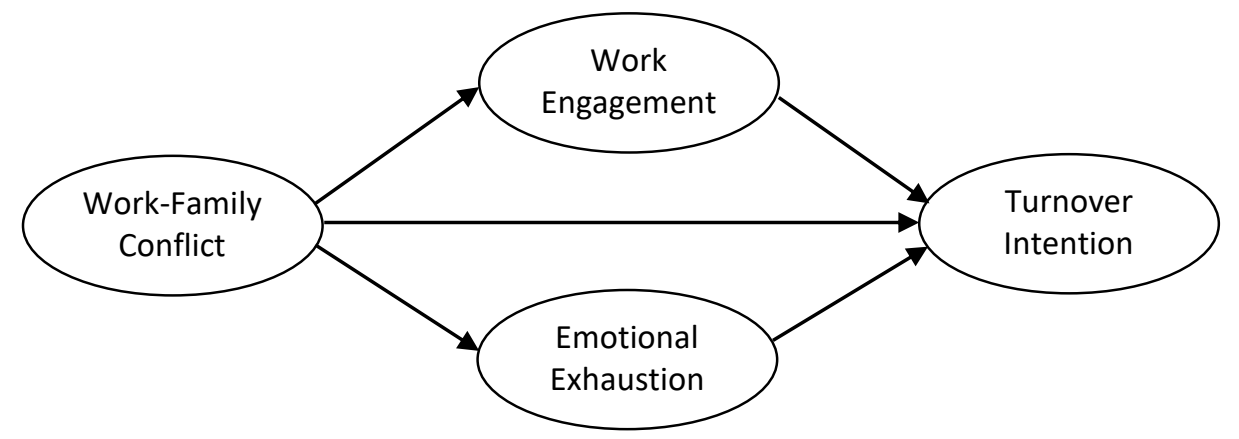

Figure 1.Conceptual Framework

Work-family conflict is one form of conflict perceived by individual that affects turnover intention among employees. Increasing work-family conflict of employees in an organization, whether conflicts that occur directly or indirectly, such as conflicts due to inequality of opinions or injustices received from their superiors and companies, will have an impact on the desire to leave employees from their companies. If the demands on work are too high and individual must be able to balance them or reconcile them with the demands of the family or household. If there is no one party (work and family) who cannot adjust, this will cause the threat of loss of personal resources owned by the employee. The relationship between work-family conflict on turnover intention or turnover intention has been studied in many previous studies with mixed results. Some studies have explained the positive link between work-family conflict on turnover intention (Boles et al., 1997; Haar, 2004; Noor \& Maad, 2008; Yavas et al., 2008). While other studies revealed that the higher the WFC conflict the lower the turnover intention, and or vice versa (Hang-yue et al., 2005; Panatik et al., 2011). Therefore, the first hypothesis in this research proposed is as follows:

$\mathrm{H} 1$ : Work-family conflict has a significant positive effect on turnover intention of women rural bank officer in district Mengwi, Bali.

Work engagement is an indication that personal (energetic) resources are brought into the organization by employees. The time spent working may sometimes be stressful, but it involves people and makes their working lives meaningful. Job engagement is defined as "a positive state, satisfying the state of mind associated with work that is characterized by strength, dedication and absorption" (Schaufeli et al., 2002). Engagement is basically an investment of resources - for the benefit of the individual but not necessarily giving an individual award. This pattern can improve labor 
relations between individuals and organizations and in return build new resources for individuals (respect and recognition, professional improvement, and social skills).

According to Greenhaus \& Beutell (1985), research in behavioral studies identifies and analyzes the concept of work-family conflict in several conditions, so that in this context, work-family conflict is more defined as a form of role conflict characterized by a mismatch between home and place responsibilities work. Pressure in the work environment were rised that could lead to work-family conflict, such as irregularity or inflexibility in working hours, job overload, many official trips, conflicts between individual employees and lack of support from supervisors or companies. Higher the workfamily conflict (WFC) would bring to lower job engagement or vice versa (Baka \& Derbis, 2012; Karatepe \& Karadas, 2016; Kesumaningsari \& Simarmata, 2014). This shows the assumption that family work conflicts have an important negative influence on job engagement. From a brief description of the relationship between these variables, the second hypothesis proposed in the study is as follows:

$\mathrm{H} 2$ : Work-family conflict has a negative significant effect on job engagement from female officers who work in rural banks in Mengwi, Bali.

The driving force in employee engagement has positive consequences for the organization because it deals with individual attitudes, intentions and behaviors. Management also plays a role in reducing company risk about human resource policies. This happen because of employees are more dedicated to creating more value for the organization, with more consistent in their interactions with customers and other stakeholders, and would not leaving the company. This explains employees who have high engagement have a lower tendency to leave the organization. The desire to leave the company is the intention to change jobs for employees so that they will tend to emerge attitudes that have a negative impact on the company which is usually shown by finding more profitable employment alternatives, less enthusiastic about work, often complaining, feeling unhappy with their work and avoiding from his responsibilities.

In addition, finding of previous research indicate that the higher the job engagement would be decrease turnover intention or vice versa (Mangi \& Jalbani, 2013; W. B. Schaufeli \& Bakker, 2004). Although there is a result of anomalies finding according to Mxenge et al., (2014) that attachment is not important for turnover intention, other researchers reinforce the negative significant influence between engagement with turnover intention (Agoi, 2015; Biswakarma, 2015; Rachman \& Dewanto, 2016). Based on the description, the third hypothesis in this study is proposed as follows:

H3: Job engagement has a significant negative effect in reducing the turnover intention of female officers who work for BPR in Mengwi, Bali.

Work-family conflicts that occur due to overlap between work and household affairs can also be defined as a form of role conflict caused by the demands of work and family cannot be aligned in several respects. An individual's inability to manage and deal with this conflict will have negative consequences, one of which is the increase in self-pressure. In the context of work, one form of pressure that is recognized is job burnout which is more indicated by emotional exhaustion. Workfamily conflict is a form of obstacle to the struggle to get resources between two important domains in an individual's life. If the demands in the work are too high and someone must reconcile them with housework, and no one has to give up something, this will cause the threat of loss of resources (Dåderman \& Basinska, 2016). Therefore work-family conflict is seen as having a negative impact on 
individual attitudes and behavior. While emotional exhaustion is a form of individual feelings for the work done. So it can be assumed that emotional exhaustion is a form of negative consequence of work-family conflict felt by individuals. The pattern of relations between the two is linearly positive, which means that the more work-family conflicts that employees feel then this will increase their tendency to feel emotionally tired. Based on the description, the fourth hypothesis in this study is proposed as follows:

H4: Work-family conflict has a positive significant effect in increasing emotional exhaustion from female officers who work in rural banks in Mengwi, Bali.

Fatigue is a psychological syndrome that arises when employees are in a stressful work environment and high job demands with low availability of resources. Work exhaustion is a syndrome condition experienced by someone when carrying out their work at the point where they experience fatigue both physically and mentally due to the demands of work (Kim and Stoner, 2008). Fatigue is a serious problem for the organization. Research shows that fatigue, absence, decreases productivity, lacks work effectiveness, reduces commitment to work, and results in turnover intention (Knudsen et al., 2006; Christina Maslach et al., 2001). The theoretical framework of fatigue (Cordes et al., 1993; Demerouti et al., 2001) says that fatigue is a key mediator of the relationship between pressure in work and a variety of attitudes or behavioral outcomes. The tendency or intention of the employee to stop working from his job is voluntary according to his own choice and this is a form of behavior. Turnover intention includes the thought of leaving the organization, looking for work elsewhere, and the desire to leave the organization. The work carried out by female officers in high-risk companies brings these employees to experience fatigue because they constantly face other parties and various problems. Certain management practices in organizations have the potential to reduce employee's emotional exhaustion and turnover intention. But employees who feel their emotional resources have been eroded have a greater tendency to withdraw until eventually they will decide to leave the organization. Based on the description above, the fifth hypothesis in this study is proposed as follows:

H5: Emotional exhaustion has a significant positive effect in increasing the turnover intention of female officers who work in rural banks in Mengwi, Bali.

Engagement occurs when a person is consciously alert and or emotionally connected to other people. Work-family conflict is a difficult thing to avoid, especially for employees who are married and work outside the home. The occurrence of this conflict when there are two fulfillment of demands, namely the demands of the family and the demands of the work that must be completed, but the employee is faced with his abilities. With this problem, employees cannot concentrate on their work tasks so that they will reduce their attachment to the work that must be done and completed. In the end a person who experiences a phase of decrease in self-attachment to his work due to the high work-family conflict that he feels will tend to decide to leave the company where he works.

Employees who experience high work-family conflicts can reduce high work attachments because resources are lost in the process of combining work and family roles. Individuals who experience high work-family conflicts feel that work competes with family to get the resources needed to fulfill their professional roles. Based on the description above, the sixth hypothesis in this study proposed is as follows: 
H6: Work-family conflict has a positive influence on turnover intention through job engagement of female officers who work in rural banks in Mengwi, Bali.

Turnover intention is the level or intention of wanting to leave the company triggered by various reasons that cause turnover intentions, usually this is due to the desire to get a better job. But workfamily conflicts have the potential to create problems for workers, where these conflicts tend to positively influence the intention to leave the company. The potential for increasing turnover intention can occur if there is pressure on work, in this case is work fatigue. The demands of high quantitative and interpersonal work cause depletion of the resources possessed by individuals, especially the energy and emotional resources they have. Because of their demands require effort and cost, especially in the form of physical, mental, and emotional energy. Furthermore, the imbalance between work and personal life can be a threat to various sources. Family work conflict means that in the work of employees using too many resources, which limits the use of these resources at home. When conditions at home cannot be managed properly, this will cause depletion of energy and emotional resources. Ultimately turnover intention can be a last resort in protecting the resources (energetic and emotional) that individuals have and preventing further personal losses. Job-family conflicts that are not managed by individuals (or the higher level of conflict) will make the tendency to become more emotionally tired will increase. In the end individuals will consider leaving the organization in order to maintain the personal resources they have. Based on the description, the seventh hypothesis in this study is proposed as follows:

H7: Work-familay conflict has a positive influence on turnover intention through emotional exhaustion from female officers who work for BPR in Mengwi, Bali.

\section{Methodology}

This study focuses on turnover intention as a dependent variable that is influenced by work-family conflict as an independent variable, and emotional exhaustion and attachment to work as intervening variables. With the hypothesis that has been proposed previously, then this study tests the hypothesis proposed by using research methods that have been designed according to the variables to be studied in order to obtain accurate research results. The discussion in this research method includes the types and sources of data, populations and samples, data collection methods, and data analysis techniques. Based on the research objectives that have been formulated, this study was conducted with a positive research approach, namely quantitative research on the measurement of constructs that form a model and analyze the relationship between one construct and another. Based on purpose of the study, the design of this study included the type of explanatory research. Explanatory research in this case aims to find an explanation or explanation of why an event or symptom occurs. This study seeks answers by analyzing the influence of work-family conflict variables, work engagement, emotional exhaustion, and turnover intention for female officers who work in Rural Banks (BPR) in distict Mengwi, Badung Regency, Bali Province. While based on the time dimension, this study was categorized as a cross-sectional study.

In this study, the location of the study was located in Mengwi, Bali, with a target population of female officers working in Rural Banks (BPR). The target sample of female officers who working in BPR is 
INTERNATIONAL JOURNAL OF ACADEMIC RESEARCH IN BUSINESS AND SOCIAL SCIENCES Vol. 9, No. 7, July, 2019, E-ISSN: 2222-6990 @ 2019 HRMARS

based on the grounds that BPR is a form of banking institution has launched an empowerment of all its employees without discrimination. The estimated time for conducting this study ranged between approximately two months, from February to March 2019, taking into account the process of collecting data through questionnaires and structured interviews with female officers who working in Rural Banks (BPR) in the district Mengwi, Badung Regency, Bali.

In order to evaluate research hypothesis, the structural equation modeling methods was used via SmartPLS software. Considering the fact that inferential statistics methods are founded on the assumption of normality of variable distribution.

\section{Instrument}

Work-family conflict. Work-family conflict in this study is the difference between work and family roles that oppose each other (Frone, Russell, \& Cooper, 1992; Greenhaus \& Beutell, 1985). While the operational resolution of family-work conflicts is work on Rural Bank because of conflicting pressures and are fully related to roles in work and in the family.

Work engagement. Work engagement is contrary to the fatigue of individual work, and in this case work engagement can be defined as a positive state, a state of mind related to work characterized by enthusiasm, dedication and absorption (Schaufeli et al., 2002). This definition is not intended to refer to a momentary or certain state, but is intended for cognitive conditions about the nature of more persistent and widespread persistence that is not focused on any particular object, event, individual or behavior (Schaufeli et al., 2006).

Emotional Exhaustion. Emotional exhaustion is conceptually interpreted as a chronic state of physical and emotional fatigue (Wright \& Cropanzano, 1998). Emotional exhaustion associated with work refers to feelings of over-intervention and exhaustion of one's emotional and physical resources (Maslach \& Jackson, 1981) because of the demands of excessive work (Wright \& Cropanzano, 1998). As one dimension of burnout, in the perspective of this study operational emotional exhaustion is a response from female officers who work at rural banks to long-term emotional and work interpersonal pressures, or in the context of unfavorable work.

Turnover Intention. Operationally turnover intentions are the desire of female officers who work for rural banks in order to leave the company or seek other employment alternatives. The indicators of turnover intention in this study that adopted the concepts from Boshoff \& Allen, (2000) and Mobley, (1982) include the following: (1) Possibility of looking for another job, (2) possible alternatives to leaving the company, (3) Having thought of leave the company. The items measuring the of each dimension employed five-point Likert-type response scales ( 1 = strongly disagree to $5=$ strongly agree).

\section{Findings and Discussion}

Discriminant validity was examined by calculating the shared variances between pairs of variables. The results demonstrated that they were lower than the average variance extracted by each latent construct. All measures proved to be reliable where the composite reliability scores were greater than 0.60. Summary statistics and correlations are given in Table I below. 
INTERNATIONAL JOURNAL OF ACADEMIC RESEARCH IN BUSINESS AND SOCIAL SCIENCES

Vol. 9, No. 7, July, 2019, E-ISSN: 2222-6990 @ 2019 HRMARS

Table 1. Mean of Variables, Standard Deviation and Intercorrelations $(n=95)$

\begin{tabular}{|c|c|c|c|c|c|c|c|}
\hline Variables & AVE & VAVE & $\begin{array}{c}\text { Mean } \\
\text { (SD) }\end{array}$ & 1 & 2 & 3 & 4 \\
\hline \multirow[t]{2}{*}{ 1.Work-Family Conflict } & & & 3.35 & $(.803)$ & & & \\
\hline & 0,725 & 0,851 & $(1.811)$ & & & & \\
\hline \multirow[t]{2}{*}{ 2.Work Engagement } & & & 2.21 & $0,288^{*}$ & $(.773)$ & & \\
\hline & 0,795 & 0,921 & $(1.983)$ & & & & \\
\hline \multirow[t]{2}{*}{ 3.Emotional Exhaustion } & & & 3.29 & $0,406 * *$ & - & $(.676)$ & \\
\hline & 0,574 & 0,773 & $(1.833)$ & & $0,223 *$ & & \\
\hline 4.Turnover Intention & & & 2.42 & $0,267^{*}$ & $-0,154$ & $0,4781 * *$ & $(.873)$ \\
\hline
\end{tabular}

Notes: ${ }^{* *} p, 0.01 ;{ }^{*} p, 0.05 ;$ Cronbach's alphas for each scale are italicized and shown in the diagonal

The majority of the correlations have proved to be significant, except for one correlation that is between work engagement and turnover intention. The results show that the highest correlation is between work-family conflict and turnover intention. This suggests that female officers who have not could longer cope with problems emerging from their conflict and therefore would like to exhibit quitting intentions.

Standart deviation and reliability scores for the variables used in the analysis in sample.The means range from 2.21 to 3.35 and the standard deviations range from 1.811 to 2.608 . The mean score for the work-family conflict was 3.35, indicating the highest average score of work-family conflict. Furthermore, the mean score for work-family conflict, work engagement, emotional exhaustion, and turnover intention were 3.35, 2.21, 3.29 and 2.42.

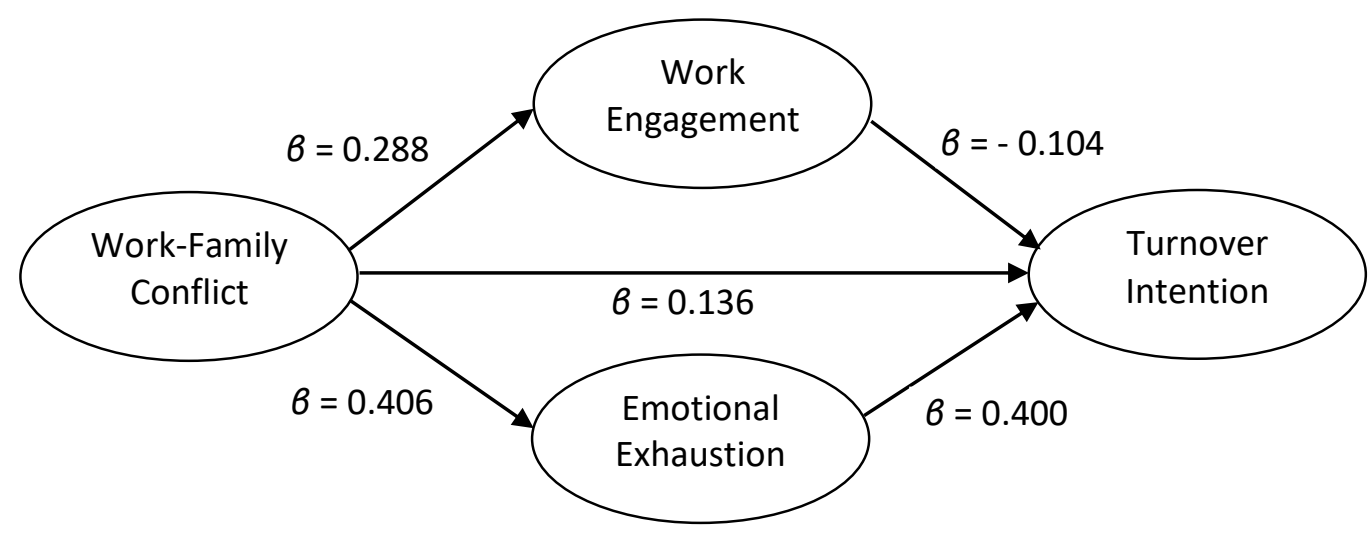

Figure 2.Path Coefficients between Variables

As figure 2 demonstrates, the pathway from work family conflict to turnover intention ( $p>0.05$ and $B=0.136)$ and the pathway from work family conflict to work engagement ( $p>0.05$ and $B=0.288$ ) is positive but insignificant. The pathway from work family conflict to emotional exhaustion is likewise positive and significant $(p<0.01$ and $B=0.406)$. Moreover, the findings reveal that pathway from 
emotional exhaustion to turnover intention is positive and significant $(p<0.01$ and $b=0.400)$. Likewise, the pathway of work engagement to turnover intention is negative and insignificant ( $p>0.05$ and $b=-0.104)$. According to these findings, the direct and positive effect of work-family conflict on emotional exhaustion, and the positive and direct effect of emotional exhaustion on turnover intention are confirmed. Except from these two relationships, another relationship effect between variables in the research framework are not confirmed.

The results indicate that emotional exhaustion strengthens the positive relationship between work-family conflict and turnover intention. Emotional exhaustion is an important mediating variable between work-family conflict and turnover intention. By strengthening the effect of work-family conflict perceived by female officers, it could increase turnover intentions. But this effect could be done indirectly but effectively through emotional exhaustion.

This research was conducted by collecting data through a survey among female officers of Rural Banks in district Mengwi, Bali. Some important results show that average respondent's answer to the variables observed in this study (work-family conflict, work attachment, emotional fatigue, turnover intention) ranged from 2.21 to 3.35. The lowest perception of rural bank female officers in district Mengwi shows about work engagement, while the highest perception is on work-family conflict. In addition, several important things that need to be conveyed include lowest score about work engagement. This reflects that the job that carried out by female officers in rural bank not enough to absorb themselves, and giving so much vigor when doing the job. The highest score among variables examined here is work-family conflict. This condition indicates that there is a high tendency of female officers who work in rural bank in having problem about managing conflict that arise from their work and family.

One of possible explanation for the lack of association between WFC, engagement and turnover intention may be female officers who work can only find jobs that are similar to the one they currently hold. Female officers may perceive other available jobs as having the same issues (conflict that arise between their job and family). If they perceive the issues as pervasive, leaving one's job may not be a viable solution. Furthermore, assessing turnover intentions in female officers may be tricky and problematic as there are some reasons that would foster female officers' intention to leave their job, such as personal or family problem, early retirement and other reasons. However, the female officers in the current study had been employed in their job for at least a year, indicating they would to still working despite the breaks.

\section{Conclusion}

The results of this study show some interesting things, including that important mediating role of the emotional exhaustion in the effect of work-family conflict on the turnover intention among female officers. There is no direct significant effect between work-family conflict and work engagement on turnover intention among female officers. This means that the effects of work-family conflict cannot directly encourage the tendency of female officers to leave the organization. In sum, although the present study does not support a fully mediated relationship between work-family conflict and turnover intention via work engagement. Inspite of that, theory of work-family conflict developed within a Western context is also generalizable to Indonesian samples with different result. 
Practically, this research shows what women should do better in an organization. In particular situation female officers could manage conflict in their roles as employees and as mothers or wife in the household, this would not fostering their feeling to be more attached with their job, while the problem is found indirectly. Companies need and manage human resources better as well as consider the role of female officers in building successful companies. Cautiously this were not easy to reduce their female officers intention to leave the organization. Rural banks must be careful to formulate HR policies regarding better management and development of human resources in furthermore going forward. The research indicates that possible areas of focus to support positive work-life balance should include approaches which encourage: building work engagement for female officers.

This research could not be separated from several limitations that can result in the emergence of deficiencies that exist in the study. Limitations identified in this study include the samples that based on personal characteristics in terms of sex, because the object of research is female officers, especially those who are married or unmarried. Another limitation showing that this research only focuses on Rural Banks in Mengwi District, Badung Regency. Generalization of results is limited to the scope of the object of research, so it cannot be used to generalize results at a broader level. Also this study conducted in one time (cross-sectional study), meaning that the study was not longitudinal, did not consider the different duration of time. This study cannot compare perception of female officers in different time frames or in continuous research so that they can provide additional information about the phenomenon of research.

\section{Acknowledgment}

The authors would like to express their gratitude to all participants who took part in this study and the three anonymous reviewers for their suggestions during the development of this article.

\section{Corresponding Author}

\section{Ida Bagus Agung Dharmanegara}

Head of Department of Management, corresponding author.

Faculty of Economic, Warmadewa University of Denpasar, Bali, Indonesia

Email: gusdhewun@gmail.com

\section{References}

Agoi, L. F. (2015). Effect of Work Engagement on Employee Turnover Intention in Public Sector, Kenya. International Journal of Economics, Commerce and Management, III(12), 426 - 440.

Baka, Ł., \& Derbis, R. (2012). Job Stressors, Job Burnout and Work Engagement: Do Work-family Conflict and Type-A Behaviour Play Roles in Regulating them? Polish Journal of Applied Psychology, 10(1), 129-155.

Bakker, A. B., Demerouti, E., \& Sanz-Vergel, A. I. (2014). Burnout and Work Engagement: The JD-R Approach. Annual Review of Organizational Psychology and Organizational Behavior, 1, 389411. https://doi.org/10.1146/annurev-orgpsych-031413-091235

Balmforth, K., \& Gardner, D. (2006). Conflict and Facilitation between Work and Family : Realizing the Outomes for Organizations. New Zealand Journal of Psychology, 35(2), 69 - 76.

Biswakarma, G. (2015). Employees" Job Engagement and Turnover Intentions in Nepalese Private 
INTERNATIONAL JOURNAL OF ACADEMIC RESEARCH IN BUSINESS AND SOCIAL SCIENCES

Vol. 9, No. 7, July, 2019, E-ISSN: 2222-6990 @ 2019 HRMARS

Commercial Banks - An Empirical Evidence. Asian Journal of Research in Business Economics and Management, 5(11), 61-78. https://doi.org/10.5958/2249-7307.2015.00194.2

Boles, J. S., Johnston, M. W., \& Hair, J. F. (1997). Role Stress, Work-Family Conflict and Emotional Exhaustion: Inter-Relationships and Effects on Some Work-Related Consequences. Journal of Personal Selling and Sales Management, 17(1), 17-28.

Boshoff, C., \& Allen, J. (2000). The influence of selected antecedents on frontline staff's perceptions of service recovery performance. International Journal of Service Industry Management, 11(1), 63-90.

Cordes, C. L., Dougherty, T. W., \& Cordes, C. L. (1993). A review and an integration of research on job burnout. Academy of Management Review, 18(4), 621-656.

Dåderman, A. M., \& Basinska, B. A. (2016). Job Demands, Engagement, and Turnover Intentions in Polish Nurses:The Role of Work-Family Interface. Frontiers in Psychology, 7, 1621. https://doi.org/10.3389/fpsyg.2016.01621

Demerouti, E., Bakker, A. B., Nachreiner, F., \& Schaufeli, W. B. (2001). The job demands resources model of burnout. Journal of Applied Psychology, 86(3), 499-512.

Frone, M. R. ., Russell, M., \& Cooper, M. L. (1992). Antecedents and Outcomes of Work-Family Conflict : Testing a Model of the Work-Family Interface. Journal of Applied Psychology, 77(1), 65 $-78$.

Geurts, S., Schaufeli, W., \& Jonge, J. De. (1998). Burnout and Intention to Leave Among Mental Health-Care Professionals: A Social Psychological Approach. Journal of Social and Clinical Psychology, 17(3), 341-362.

Greenberg, J., \& Baron, R. A. (2008). Behavior in Organizatation (9th ed.). New York: Prentice Hall Pearson International Edition.

Greenhaus, J. ., \& Beutell, N. J. (1985). Sources of conflict between work and family roles. Academy of Management Review, 10(1), 76-88.

Greenhaus, J. H., \& Powell, G. N. (2006). When Work and Family Are Allies : A Theory of Work-Family Enrichment. Academy of Management Review, 31(1), 72-92.

Haar, J. M. (2004). Work-Family Conflict and Turnover Intention : Exploring the Moderation Effects of Perceived Work-family support. New Zealand Journal of Psychology, 33(1), 35 - 39.

Handini, R. E., Haryoko, S. F., \& Yulianto, A. (2014). Hubungan Antara Work-Family Conflict dan Keterikatan Kerja Pada Ibu Bekerja. Jurnal NOETIC Psychology, 4(2), 169 - 180.

Hang-yue, N., Foley, S., \& Loi, R. (2005). Work role stressors and turnover intentions: a study of professional clergy in Hong Kong. The International Journal of Human Resource Management, 16(11), 2133-2146. https://doi.org/10.1080/09585190500315141

Karatepe, O. M., \& Karadas, G. (2016). Service employees' fit, work-family conflict, and work engagement. Journal of Services Marketing, 30(5), 554 - 566. https://doi.org/10.1108/JSM-022015-0066

Kesumaningsari, N. P. A., \& Simarmata, N. (2014). Konflik Kerja-Keluarga dan Work Engagement Karyawati Bali Pada Bank di Bali. Jurnal Psikologi Udayana, 1(3), 493-506.

Knudsen, H. K., Ducharme, L. J., \& Roman, P. M. (2006). Counselor emotional exhaustion and turnover intention in therapeutic communities. Journal of Substance Abuse Treatment, 31, 173- 180.

Lathifah, I. (2008). Pengaruh Konflik Pekerjaan-Keluarga Terhadap Turnover Intentions dengan 
INTERNATIONAL JOURNAL OF ACADEMIC RESEARCH IN BUSINESS AND SOCIAL SCIENCES

Vol. 9, No. 7, July, 2019, E-ISSN: 2222-6990 @ 2019 HRMARS

Kepuasan Kerja sebagai Variabel Intervening (Studi Empiris pada Auditor Kantor Akuntan Publik Di Indonesia). Universitas Diponegoro Semarang.

Lee, R. T., \& Ashforth, B. E. (1993). A Further Examination of Managerial Burnout: Toward integrated Model. Journal of Organizational Behaviour, 14, 3-20.

Lilly, J. D., Duffy, J. A., \& Virick, M. (2006). A gender-sensitive study of McClelland's needs, stress, and turnover intent with work-family conflict. Women in Management Review, 21(8), 662 - 680. https://doi.org/10.1108/09649420610712045

Mangi, R. A., \& Jalbani, A. A. (2013). Mediation of Work Engagement between Emotional Exhaustion, Cynicism and Turnover Intentions. International Journal of Management Sciences and Business Research, 2(7), $45-54$.

Maslach, C., \& Jackson, S. E. (1981). The measurement of experienced bournout. Journal of Occupational Behavior, 2, 99-113.

Maslach, C., \& Jackson, S. E. (1981). The Measurement of Experienced Burnout. Journal of Occupational Behaviour, 2(2), 99-113. https://doi.org/10.1002/job.4030020205

Maslach, C., \& Leiter, M. P. (1997). The truth about burnout: how organizations cause personal stress and what to do about it. New York: Jossey-Bass.

Maslach, C., Schaufeli, W. B., \& Leiter, M. D. (2001). Job burnout. Annual Review of Psychology, 52, 397 - 422. https://doi.org/10.1146/annurev.psych.52.1.397

Mobley, W. H. (1982). Employee turnover: Causes, consequences, and control. Reading: MT: AddisonWesley.

Mxenge, S. V., Dywili, M., \& Bazana, S. (2014). Job Engagement and Employees' Intention to Quit Among Administrative Personnel at The University of Fort Hare in South Africa. International Journal of Research In Social Sciences, 4(5), $129-144$.

Netemeyer, R. G., Boles, J. S., \& McMurrian, R. (1996). Development and Validation of Work-Family Conflict and Family-Work Conflict Scales. Journal of Applied Psychology, 81(4), $400-410$.

Noor, S., \& Maad, N. (2008). Examining the Relationship between Work Life Conflict, Stress And Turnover Intentions among Marketing Executives in Pakistan. International Journal of Business and Management, 3(11), $93-102$.

Panatik, S. A. B., Badri, S. K. Z., Rajab, A., Rahman, H. A., \& Shah, I. M. (2011). The Impact of Work Family Conflict on Psychological Well-Being among School Teachers in Malaysia. Procedia-Social and Behavioral Sciences, 29, $1500-1507$.

Rachman, L., \& Dewanto, A. (2016). Pengaruh Employee Engagement terhadap Kepuasan Kerja dan Turnover Intention Perawat (Studi pada Rumah Sakit Wava Husada Kepanjen Malang). Jurnal Aplikasi Manajemen (JAM), 14(2), 322 - 333. https://doi.org/10.18202/jam23026332.14.2.14

Reed, S. A., Kratchman, S. H., \& Strawser, R. H. (1994). Job Satisfaction, Organizational Commitment, and Turnover Intentions of United States Accountants: The Impact of Locus of Control and Gender. Accounting, Auditing \& Accountability Journal, 7(1), 31-58.

Ribeiro, S., Bosch, A., \& Becker, J. (2016). Retention of women accountants: The interaction of job demands and job resources. SA Journal of Human Resource Management/SA Tydskrif Vir Menslikehulpbronbestuur, 14(1), 759. https://doi.org/10.4102/sajhrm. v14i1.759

Saks, A. M. (2006). Antecedents and consequences of employee engagement. Journal of Managerial Psychology, 21(7), 600-619. 
Santosa, T., \& Cintya, E. (2012). Memahami dan Mendorong Terciptanya Employee Engagement Dalam Organisasi. Jurnal Manajemen, 11(2), 207 - 215.

Schaufeli, W. B., \& Bakker, A. B. (2004). Job demands, job resources, and their relationship with burnout and engagement: a multi-sample study. Journal of Organizational Behavior, 25, 293315. https://doi.org/10.1002/job.248.

Schaufeli, W. B., \& Bakker, A. B. (2010). The conceptualization and measurement of work engagement: A review. In A. B. Bakker \& M. P. Leiter (Eds.), Work engagement: A handbook of essential theory and research. New York: NY: Psychology Press.

Schaufeli, W. B., Bakker, A., \& Salanova, M. (2006). The measurement of work engagement with a short questionnaire: a cross-national study. Educational and Psychological Measurement, 66(4), 701-716.

Schaufeli, W. B., Salanova, M., Gonzalez-Roma, V., \& Bakker, A. B. (2002). The Measurement of Engagement and Burnout: A Confirmatory Factor Analytic Approach. Journal of Happiness Studies, 3, 71-92.

Thirapatsakun, T., Kuntonbutr, C., \& Mechinda, P. (2014). The Relationships among Job Demands, Work Engagement, and Turnover Intentions in the Multiple Groups of Different Levels of Perceived Organizational Supports. Universal Journal of Management, 2(7), 272-285. https://doi.org/10.13189/ujm.2014.020703.

Wright, T. A., \& Cropanzano, R. (1998). Emotional Exhaustion as a Predictor of Job Performance and Voluntary Turnover. Journal of Applied Psychology, 83(3), 486-493.

Yavas, U., Babakus, E., \& Karatepe, O. M. (2008). Attitudinal and behavioral consequences of workfamily conflict and family-work conflict - Does gender matter? International Journal of Service Industry Management, 19(1), 7-31.

Zhang, M., Griffeth, R. W., \& Fried, D. D. (2012). Work-family conflict and individual consequences. Journal of Managerial Psychology, 27(7), 696-713. https://doi.org/10.1108/02683941211259520. 